\title{
Swimming depth of migrating silver eels Anguilla japonica released at seamounts of the West Mariana Ridge, their estimated spawning sites
}

\author{
Jun Aoyama ${ }^{1, *}$, Karen Hissmann ${ }^{2}$, Tatsuki Yoshinaga ${ }^{3}$, Seiji Sasai ${ }^{3}$, Tomoko Uto ${ }^{3}$, \\ Hiroshi Ueda ${ }^{4}$ \\ 'Ocean Research Institute, University of Tokyo, 1-15-1 Minamidai, Nakano, Tokyo 164-8639, Japan \\ ${ }^{2}$ Max-Plank-Institute of Animal Behaviour and Physiology, 82319 Seewiesen, Germany \\ ${ }^{3}$ Irago Institute, Atsumi-cho, Atsumi-gun, Aichi 441-36, Japan \\ ${ }^{4}$ Toya Lake Station for Environmental Biology, Faculty of Fisheries, Hokkaido University, 122 Tsukiura, Abuta-cho, \\ Abuta-gun, Hokkaido 049-5723, Japan
}

\begin{abstract}
Five hormone-treated female Japanese silver eels Anguilla japonica were tagged with ultrasonic transmitters and released by submersible in the West Pacific at seamounts of the West Mariana Ridge, their supposed spawning grounds. Four eels were tracked for 60 to $423 \mathrm{~min}$ in the vicinity of the seamounts. They did not settle at the seamounts but swam at a mean speed of $0.37 \mathrm{~m} \mathrm{~s}^{-1}$ into open water above deep ground. Their mean swimming depth ranged from 81 to $172 \mathrm{~m}$. Experiments suggest that pre-matured A. japonica migrate to their spawning grounds in temperate warm water and at shallow depths.
\end{abstract}

KEY WORDS: Freshwater eel - Spawning migration - Biotelemetry - Seamounts - Swimming depth · Anguilla japonica

\section{INTRODUCTION}

The Japanese eel Anguilla japonica migrates thousands of kilometers from its freshwater growth habitats to its spawning sites in the open ocean far from the continental coasts. The Japanese eel is supposed to spawn west of the Mariana Islands in the West Pacific (Tsukamoto 1992), although spawning sites have not been determined yet, because no adult eels have been observed in the estimated spawning area. The offshore spawning migration of adult eels, i.e. their route through the oceans, swimming depth and orientation, is still a mystery.

Numerous tracking studies by means of ultrasonic telemetry have been conducted with migratory silver

\footnotetext{
•E-mail: jaoyama@ori.u-tokyo.ac.jp
}

eels (e.g. Tesch 1978, Jellyman et al. 1996, Kuo et al. 1996, Parker \& McCleave 1997, Barbin et al. 1998). However, tracking studies in the open ocean have been made only with European eels (e.g. Tesch 1989, Westin 1990, Tesch et al. 1991. Fricke \& Kaese 1995), and never with Japanese eels in the West Pacific. Here, we report on the first tracking experiments conducted with hormone-treated Japanese silver eels at seamounts of the West Mariana Ridge, the speculated spawning sites of $A$. japonica (Fricke \& Tsukamoto 1998).

\section{MATERIALS AND METHODS}

This study was undertaken as part of the summer 1998 research cruise of the 'Hakuho-Maru', Ocean Research Institute, University of Tokyo 
Table 1. Details of silver eels examined and each tracking experiments

\begin{tabular}{|c|c|c|c|c|c|c|c|c|c|c|}
\hline $\begin{array}{l}\text { Eel } \\
\text { no. }\end{array}$ & $\begin{array}{c}\text { Body } \\
\text { length } \\
(\mathrm{cm})\end{array}$ & $\begin{array}{c}\text { Body } \\
\text { weight } \\
\text { (g) }\end{array}$ & $\begin{array}{c}\text { Oocytes } \\
\text { diameter } \\
(\mu \mathrm{m})\end{array}$ & $\begin{array}{c}\text { Date } \\
\text { of tracking }\end{array}$ & $\begin{array}{l}\text { Location } \\
\text { of release }\end{array}$ & $\begin{array}{c}\text { Time } \\
\text { of release } \\
(\mathrm{h})\end{array}$ & $\begin{array}{l}\text { Depth } \\
\text { of release } \\
(\mathrm{m})\end{array}$ & $\begin{array}{c}\text { Temperature } \\
\text { at release } \\
\left({ }^{\circ} \mathrm{C}\right)\end{array}$ & $\begin{array}{l}\text { Behaviour } \\
\text { at release }\end{array}$ & $\begin{array}{c}\text { Total duration } \\
\text { of tracking } \\
\text { (min) }\end{array}$ \\
\hline 1 & 76.0 & 599 & $250-300$ & $\begin{array}{l}10 \text { Jun } \\
1998\end{array}$ & $\begin{array}{l}\text { East slope } \\
\text { Arakane }\end{array}$ & $12: 13$ & 324 & 13.2 & $\begin{array}{l}\text { Withdraws } \\
\text { under rock }\end{array}$ & - \\
\hline 2 & 82.2 & 840 & $250-300$ & $\begin{array}{l}\text { 12 Jun } \\
1998\end{array}$ & $\begin{array}{l}\text { East slope } \\
\text { Arakane }\end{array}$ & $09: 21$ & 210 & 18.7 & $\begin{array}{l}\text { Moves } \\
\text { downslope }\end{array}$ & 85 \\
\hline 3 & 83.0 & 672 & $300-500$ & $\begin{array}{l}14 \text { Jun } \\
1998\end{array}$ & $\begin{array}{l}\text { East slope } \\
\text { Arakane }\end{array}$ & $09: 32$ & 176 & 24.4 & $\begin{array}{l}\text { Moves } \\
\text { downslope }\end{array}$ & 166 \\
\hline 4 & 69.0 & 540 & $400-450$ & $\begin{array}{c}16 \text { Jun } \\
1998\end{array}$ & $\begin{array}{l}\text { East slope } \\
\text { Pathfinder }\end{array}$ & $09: 30$ & 185 & 23.5 & $\begin{array}{l}\text { Moves } \\
\text { downslope }\end{array}$ & 60 \\
\hline 5 & 75.5 & 675 & - & $\begin{array}{c}18 \text { Jun } \\
1998\end{array}$ & $\begin{array}{l}\text { West slope } \\
\text { Arakane }\end{array}$ & $10: 16$ & 215 & 21.4 & $\begin{array}{l}\text { Moves } \\
\text { vertical }\end{array}$ & 423 \\
\hline
\end{tabular}

Five female cultivated Japanese eels were artificially induced to maturity by repeated injection of salmon pituitary extract (Yamamoto et al. 1974). During the voyage, eels were held unfed in an aerated seawater tank at $23^{\circ} \mathrm{C}$. The water inside the tank was continuously replaced by fresh, cooled surface seawater.

One day before tracking, activated transmitters were attached surgically using nylon string to the back of the eel in front of the dorsal fin, and a biopsy was conducted to observe their oocyte diameter, under anaesthetization.

Release took place about $12 \mathrm{~h}$ later to allow tagged eels to recover from anesthetization and handling stress.

The tracking system (VEMCO/Canada) included a depth-decoding ultrasonic receiver, a staff-mounted hydrophone and 5 pressure-sensing acoustic transmitters $(9 \mathrm{~g}$ weight in air, length $48 \mathrm{~mm}$, width $16 \mathrm{~mm}$, frequencies $50.0,60.0,65.5,69.0,76.8 \mathrm{kHz}$, pressure limit 1000 PSI, life capacity $12 \mathrm{~d}$ ).

The eels were transferred shortly before release to a releasing device made of a PVC tube and were taken by the submersible 'JAGO' to depths between 176 and $324 \mathrm{~m}$ (Table 1). Eels were released at the slope of the seamounts after a short acclimatization to the final depth. The tagged eel was tracked from an inflatable boat equipped with outboard engine, the position of which was followed by GPS. Depth values were manually recorded in intervals of 1 to $5 \mathrm{~min}$.

Four eels (Nos. 1, 2, 3, and 5) were released at the Arakane seamount $\left(15^{\circ} 37.6^{\prime} \mathrm{N}, 142^{\circ} 15.8^{\prime} \mathrm{E}\right)$ and 1 eel (No. 4) at the Pathfinder seamount $\left(16^{\circ} 30.0^{\prime} \mathrm{N}, 143^{\circ}\right.$ 9.1'E) (Table 1). Tracking was conducted during daytime hours only.

On the tracking days, depth-temperature profiles between surface and $400 \mathrm{~m}$ depth were continuously collected by a CTD probe (Sea-Bird SBE 9) attached to the submersible; current speed and direction close to the slope of the seamount were estimated visually by the submersible crew.

\section{RESULTS}

\section{Oceanographic features}

The vertical temperature profiles measured from on board the submersible revealed average water temperatures of $29.5^{\circ} \mathrm{C}$ at the surface (min.-max. 29.2 to $\left.29.8^{\circ} \mathrm{C}\right), 27.4^{\circ} \mathrm{C}$ at $100 \mathrm{~m}\left(26\right.$ to $\left.28.6^{\circ} \mathrm{C}\right), 20.9^{\circ} \mathrm{C}$ at $200 \mathrm{~m}$ $\left(18.3\right.$ to $\left.23.2^{\circ} \mathrm{C}\right), 15.6^{\circ} \mathrm{C}$ at $300 \mathrm{~m}\left(14.5\right.$ to $\left.17.1^{\circ} \mathrm{C}\right)$ and $10.9^{\circ} \mathrm{C}$ at $400 \mathrm{~m}$ depth $\left(9.6\right.$ to $12.3^{\circ} \mathrm{C}$ ). High temperature fluctuations of up to $6^{\circ} \mathrm{C}$ were encountered below $150 \mathrm{~m}$.

The most dominant current direction at the surface and in shallow water down to $100 \mathrm{~m}$ was E-W. Below $100 \mathrm{~m}$ we frequently faced at both seamounts currents from north to south and from south to north; changes could be sudden. Current velocity was mainly moderate but could also sometimes reach 1 knot.

\section{Tracking experiments}

The body weight of the eels used for tracking was 550 to $850 \mathrm{~g}$; the diameter of their oocytes ranged from 0.3 to $0.5 \mathrm{~mm}$ (Table 1), which corresponds to oocytes of Japanese eels in the mid vitellogenesis stage (Yamamoto \& Yamauchi 1974).

Continuous tracking in vicinity of the seamounts lasted between 60 and $423 \mathrm{~min}$ (Table 1 ); eel No. 1 was lost shortly after being released.

\section{Vertical movements}

After release, the 4 eels we tracked first ascended fast to depths shallower than the depth where they were released, and then they moved up and down between 33 and $259 \mathrm{~m}$. The temperature at these depths ranged from 18 to $28^{\circ} \mathrm{C}$. The mean depths of all 
Fig. 1. Anguilla japonica. Swimming depth of 4 tagged Japanese eels released at Arakane or Pathfinder seamounts in the Pacific Ocean. Release depth in each experiment (Nos. 2 to 5) is indicated as a black box (with fish number) on the vertical axis

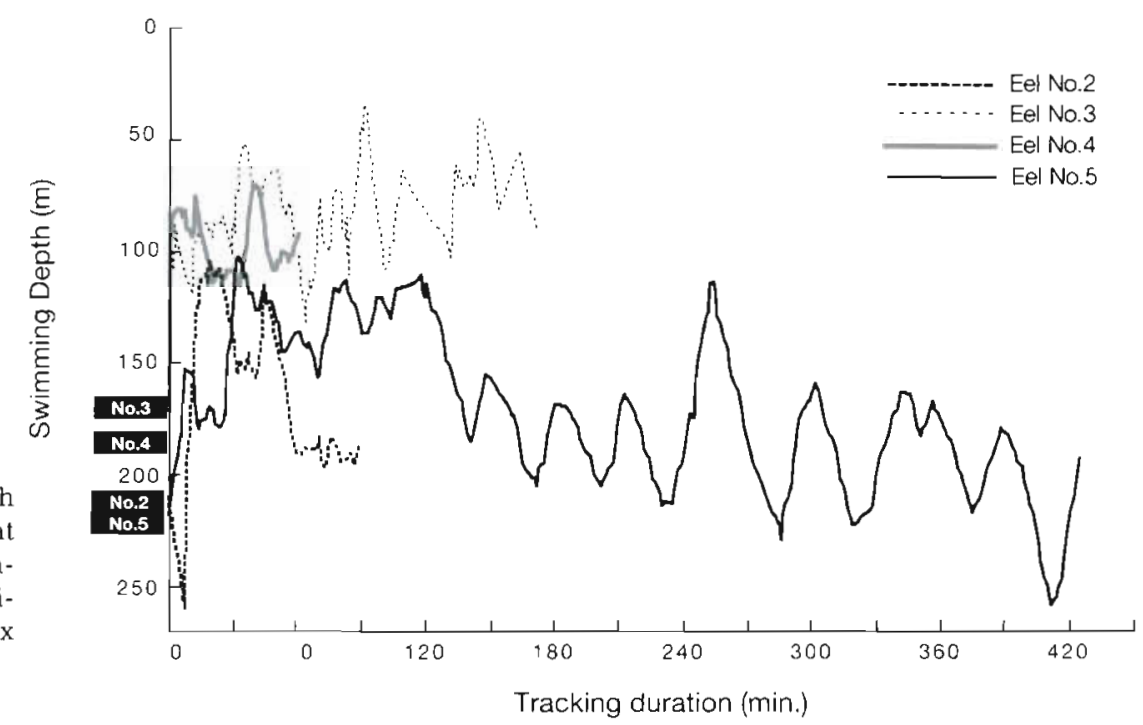

the eels lay above their release depths (Fig. 1) Most of the time was spent in depths between 100 and $200 \mathrm{~m}$ at temperatures of 21 to $27^{\circ} \mathrm{C}$. None of the eels descended into water deeper than $260 \mathrm{~m}$ and temperatures below $18^{\circ} \mathrm{C}$. Eel No. 2, tracked for $1 \frac{1}{2} \mathrm{~h}$, exhibited a depth preference for 100 to $200 \mathrm{~m}$ (mean $166 \mathrm{~m}$ ); eel No. 3 went into shallow water close to the edge of the reef (mean $81 \mathrm{~m}$ ). Eel No. 4, followed for $1 \mathrm{~h}$, swam in a relatively narrow depth range between 70 and $120 \mathrm{~m}$ (mean $98 \mathrm{~m}$ ) and temperatures of 26 to $27^{\circ} \mathrm{C}$. The longest track was performed with eel No. 5 , which was followed for $7 \mathrm{~h}$. The eel moved up and down in depths between 103 and $259 \mathrm{~m}$ (mean $172 \mathrm{~m}$ ) and the temperature of 18 to $28^{\circ} \mathrm{C}$. Its track shows a slight increase in depths towards the end of the tracking in the late afternoon (Fig. 1).

\section{Horizontal movements}

Eels Nos. 2 and 4 left the edge of the seamounts in a south/south-east direction and went into open water, where they were finally lost above deep ground (Figs. $2 \& 3$ ). The distance between the releasing position and the position of the last signal detection was $1850 \mathrm{~m}$ for eel No. 2 and $1230 \mathrm{~m}$ for eel No. 4. Both maintained a relatively straight course in direction of $171^{\circ}$ and $175^{\circ}$, respectively. Eel No. 3 showed a rather strong zig-zag or back and forth movement close to the edge of the reef. Its behaviour appeared to be abnormal and strongly resembled the movements of a cruising shark; sharks were frequently seen at the top and edges of the seamounts. Eel

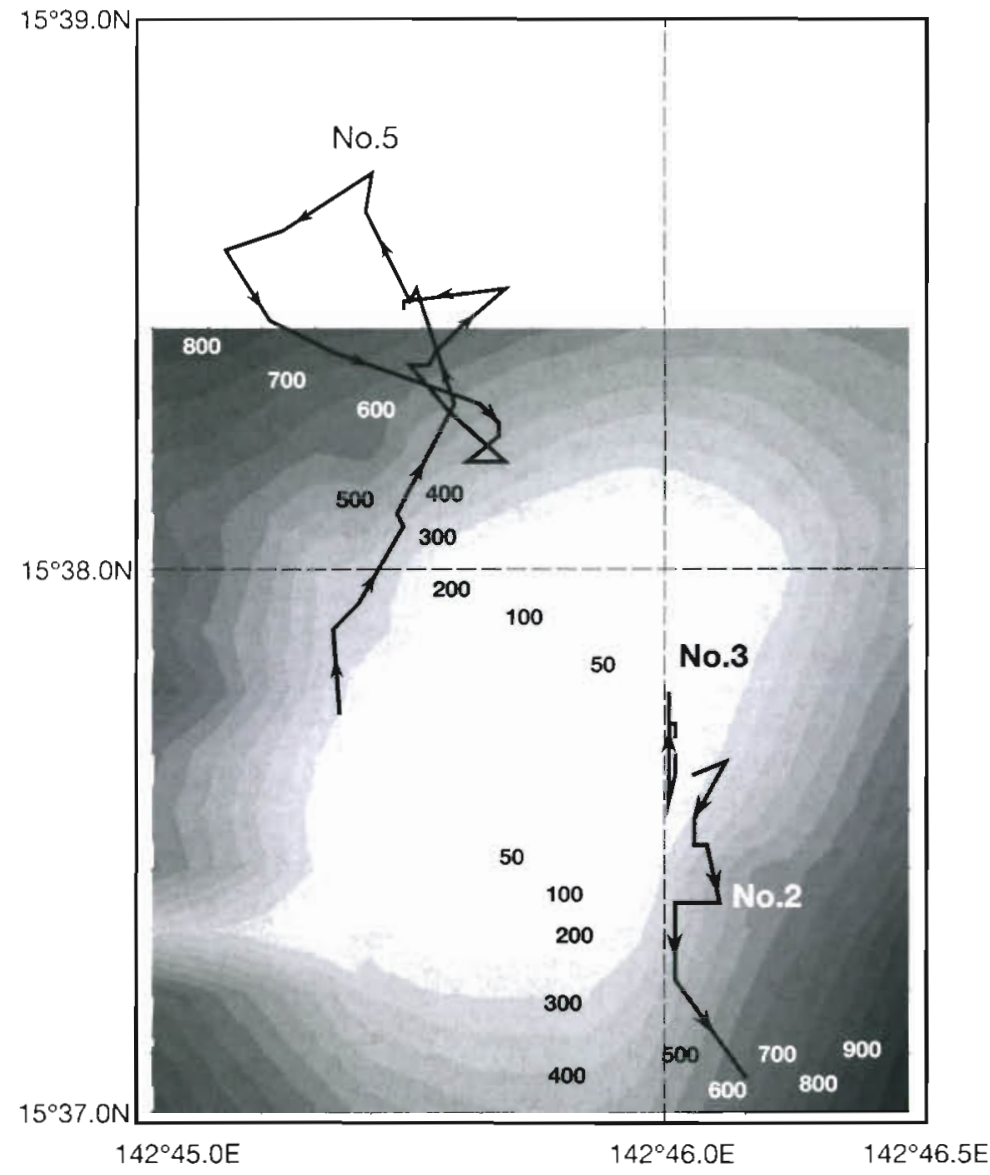

Fig. 2. Anguilla japonica. Directional swimming patterns of 3 eels (Nos. 2, 3, and 5) released at the Arakane seamount. The seamount is presented bathymetrically 


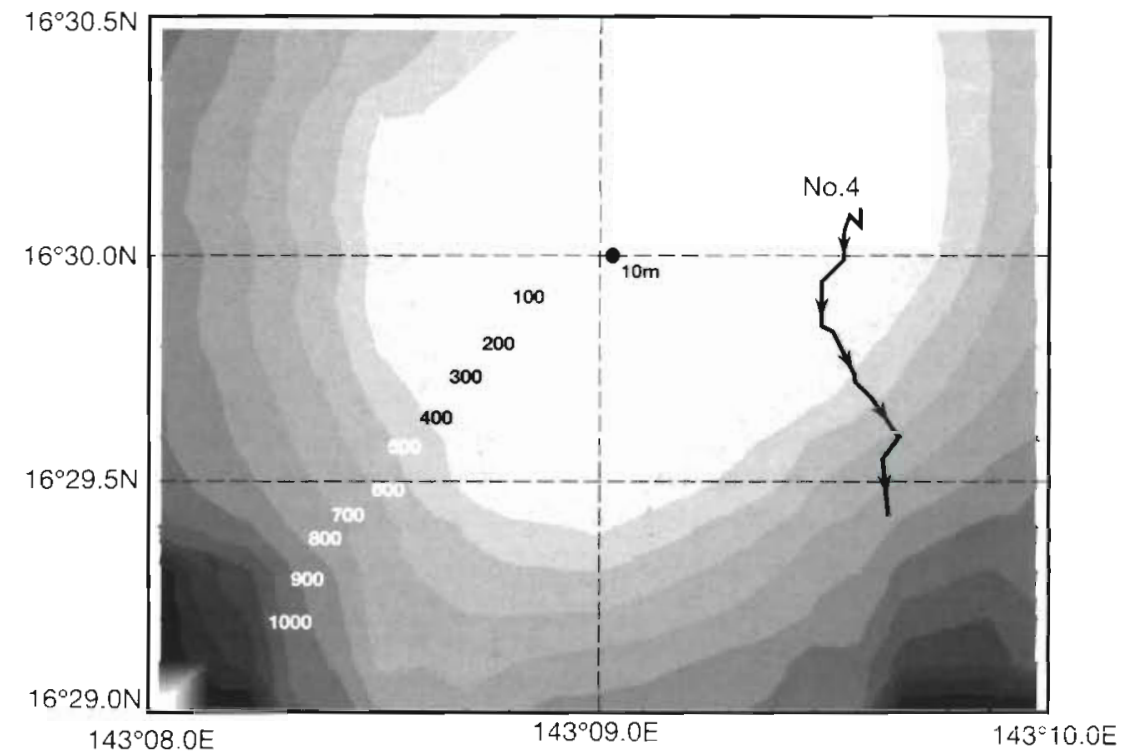

Fig. 3. Anguilla japonica. Directional swimming patterns of eel No. 4 released at the Pathfinder seamount. The seamount is presented bathymetrically

No. 5 also left the reef but moved first to the north (Fig, 2). Then, after $2 \mathrm{~h}$ at a maximum distance of $1840 \mathrm{~m}$ from the release position, it changed direction and swam back to the vicinity of the reef (distance to releasing position $1350 \mathrm{~m}$ ) but remained above deep ground ( $<500 \mathrm{~m}$ ) (Fig. 2). Three hours later it again left the vicinity of the seamount and went in a north-west direction. After $7 \mathrm{~h}$, tracking of eel No. 5 was abandoned because of darkness. The horizontal swimming speed (speed over ground) of eel No. 2 was $0.36 \mathrm{~m} \mathrm{~s}^{-1}$, eel No. 4 swam $0.44 \mathrm{~m} \mathrm{~s}^{-1}$, and eel No. 5 exhibited $0.3 \mathrm{~m} \mathrm{~s}^{-1}$ (average $0.37 \mathrm{~m} \mathrm{~s}^{-1}$ ). Eels Nos. 2 and 5 clearly swam in the dominant current directions during the tracking days, to the south and north, respectively.

Despite intensive surveys around the seamounts none of the tagged eels were relocated on the days following the tracking day, suggesting that they all left the seamounts

\section{DISCUSSION}

For the first time tagged fish were brought to depth and released from a submersible. Exposure to surface water temperature, in the West Pacific some degrees higher than the temperature to which animals were acclimatized during transport, was kept as short as possible. The impact of release by submersible on the behaviour of the fish is difficult to assess, but we believe that the method can alleviate the environmental stress on tagged fish when being released. Moreover, a further advantage of the submersible was that it was able to find one of the tagged eels hiding under a rock just after release, where it could not be detected at all from the surface.
Fricke \& Tsukamoto (1998) suggested that aggregation of matured Japanese eels, mate allocation and spawning might take place close to the scamounts studied here, which rise from very deep to very shallow water. The main task of our tracking study was therefore to investigate the behaviour of eels released close to the slope of these seamounts in an advanced stage of maturation. Our submersible surveys at the Arakane and Pathfinder seamounts revealed that the slopes of both seamounts are very steep $\left(45^{\circ}\right.$ to $\left.60^{\circ}\right)$, partly smooth and partly covered with boulders, dead coral pebbles and cobbles eroded from the shallower carbonate platforms. These sites could act as shelters for eels. However, 3 of the 5 eels we followed left the seamounts and swam into open water. They did not settle at the slope as was strongly expected for a bottom-dwelling fish. The eels we used were not in the final stage of maturation and still in the migratory phase. Thus our results rather provide clues about the migration behaviour of Japanese silver eels than about their behaviour at or near the spawning grounds.

The eels we tracked showed a conspicuous preference for shallow water (preferred depth 100 to $200 \mathrm{~m}$ ) and relatively high temperatures $\left(18\right.$ to $\left.28^{\circ} \mathrm{C}\right)$. Our findings therefore support the hypothesis of Kleckner \& McCleave (1985) that the eel's migration in the open ocean occurs in the meso-or epi-pelagic zone and thus is a shallow-water phenomenon. Haro (1991) hypothesized that migratory Anguilla will be found at times, locations and depths that correspond to their final preferred temperature, which he found to lie between 17 and $20^{\circ} \mathrm{C}$ for unmatured as well as matured silver eels. $17^{\circ} \mathrm{C}$ was measured in the West Pacific on average at $250 \mathrm{~m}$, and $20^{\circ} \mathrm{C}$ at $210 \mathrm{~m}$ depth, i.e. in water slightly deeper than the mean swimming depth of the eels we 
tracked. The European silver eels tracked by Fricke \& Kaese (1995) in the Sargasso Sea exhibited an average swimming depth of 250 and $269 \mathrm{~m}$ in temperatures of 18.7 to $18.8^{\circ} \mathrm{C}$. Tesch (1989) even observed a conspicuous day and night difference in the average swimming depth of the European silver eels he released in the Mediterranean (344 m during daylight, $196 \mathrm{~m}$ during darkness). Our study was conducted during daylight hours only; thus comparative data are lacking. Nevertheless, the general comparison reveals that the Japanese silver eels preferred slightly shallower water depths than the tracked European eels. The average horizontal swimming speed of all the eels released by Tesch (1989) in the Mediterranean was computed to be $0.3 \mathrm{~m} \mathrm{~s}^{-1}$ (Tesch 1989); those he released in the Sargasso Sea made a horizontal progress of 0.1 to $0.8 \mathrm{~m}$ $\mathrm{s}^{-1}$. Our data on the horizontal swimming speed of Japanese eels matches these findings well; they all moved relatively slowly.

The present study revealed preferred swimming depths of maturing free-swimming silver Japanese eel. The next step should be long-term tracking experiments using fully matured silver eels which will provide greater information about spawning migration and spawning depth of the Japanese eel.

Acknowledgements The authors are grateful to the captain and crew of the RV 'Hakuho-Maru', and to Drs K. Tsukamoto and $H$. Fricke for general support of the study and for their comments on the ms. We thank Drs K. Aida, Y. Suzuki and M Lokman, who helped in the hormone treatment of the eels Our friend and submersible pilot J. Schauer safely released the eels; U. Kohler and G. Hassenpflug assisted in the submersible handling. Many thanks for their help on board and during tracking to $M$. Nagata, T Inagaki, K. Kubokawa, S. Ishikawa, Y. Kimura, H. Hasumoto, S. Watanabe, and A. Shinoda. Appreciation is extended to Dr J. B. K. Leonard (JSPS/ NSF Postdoctoral Fellow) for the critical reading of the manuscript. This study was funded by the following sources: the Program 'Research for the Future' (No. JSPS-RFTF 97L00901) and Research Fellowships for J.A. from the Japanese Society for the Promotion of Science, Touwa Shokuhin Shinkoukai, the Japanese Ministry of Education, Science and Culture of Japan (grant Nos. 08456094, 10460081, and 080411399), the Eel Research Foundation of Nobori-kai, the German Research

Editorial responsibility: Otto Kinne (Editor) Oldendorf/Luhe, Germany
Council (Project No. FR 369/16-1) and the Max-Planck-Institute Seewiesen

\section{LITERATURE CITED}

Barbin GP, Parker SJ, McCleave JD (1998) Olfactory clues play a critical role in the estuarine migration of silverphase American eels. Environ Biol Fish 52:281-291

Fricke H, Kaese R (1995) Tracking of artificially matured eels (Anguilla anguilla) in the Sargasso Sea and the problem of the eel's spawning site. Naturwissenschaften 82:32-36

Fricke H, Tsukamoto K (1998) Seamounts and the mystery of eel spawning. Naturwissenschaften 85:290-291

Haro AJ (1991) Thermal preferenda and behavior of Atlantic eels (genus Anguilla) in relation to their spawning migration. Environ Biol Fish 31:171-184

Jellyman DJ, Glova GJ, Todd PR (1996) Movements of shortfinned eels Anguilla australis, in Lake Ellesmere, New Zealand: results from mark-recapture studies and sonic tracking. NZ J Mar Freshw Res 30:371-381

Kleckner RC, McCleave JD (1985) Spatial and temporal distribution of American eel larvae in relation to north Atlantic Ocean current systems. Dana 4:67-92

Kuo CL, Nakamura A, Tsukamoto K, Suzuki K, Liao IC (1996) Tracking of Japanese eel Anguilla japonica by ultrasonic transmitter in the southwestern waters of Taiwan. J Fish Soc Taiwan 23:279-287

Parker SJ, McCleave JD (1997) Selective tidal stream transport by American eels during horning movements and estuarine migration. J Mar Biol Assoc UK 77:871-889

Tesch FW (1978) Telemetric observations on the spawning migration of the eel (Anguilla anguilla) west of the European continental shelf. Environ Biol Fish 3:203-209

Tesch FW (1989) Changes in swimming depth and direction of silver eels (Anguilla anguilla L.) from the continental shelf to the deep sea. Aquat Living Resour 2:9-20

Tesch FW, Westerberg H, Karlsson L (1991) Tracking studies on migrating silver eels in the central Baltic. Meeresforschung 33:183-196

Tsukamoto $\mathrm{K}$ (1992) Discovery of the spawning area for Japanese eel. Nature 356:789-791

Westin L (1990) Orientation mechanisms in migrating European silver eel Anguilla anguilla: temperature and olfaction. Mar Biol 106:175-180

Yamamoto K, Yamauchi K (1974) Sexual maturation of Japanese eel and production of eel larvae in the aquarium Nature 251:220-221

Yamamoto K, Morioka T, Hiroi O, Omori M (1974) Artificial maturation of female Japanese eels by the injection of salmonid pituitary. Nippon Suisan Gakkaishi 40:1-7

Submitted: February 23, 1999; Accepted: May 12, 1999

Proofs received from author(s): September 9, 1999 